\title{
Physical and Mechanical Properties of Selected Wood Species in Tropical Rainforest Ecosystem, Ondo State, Nigeria
}

\author{
Jamala, G. $Y^{1^{*}}$, Olubunmi, S.O ${ }^{2}$, Mada, D. ${ }^{1}$ and Abraham, $\mathrm{P}^{1}$ \\ ${ }^{I}$ Adamawa State College of Agriculture, Dept. of Forestry Technology, Ganye, Nigeria \\ ${ }^{2}$ Federal University, Dept. of Forestry and Wildlife Management, Wukari, Taraba State, Nigeria
}

\begin{abstract}
This study was conducted to determine the effect of wood species on physical and mechanical properties of some selected wood in the Tropical Rainforest Ecosystem, Ondo State, Nigeria. The experiment was laid out in Complete Block Design (CBD). Department of Forestry and Wood Technology, Federal University of Technology Akure, Ondo State, Nigeria, between May 2012 and September 2012. The wood species includes Meliceae excelsa, Khaya ivorensis, Triplochiton scleroxylon, Afzelia africana and Celtis mildbraedii. The wood were machined and trimmed to standard size of $20 \mathrm{~mm} X 20 \mathrm{~mm} \mathrm{X} 60 \mathrm{~mm}$ for the determination of physical properties and $10 \mathrm{~mm} \times 10 \mathrm{~mm}$ X $300 \mathrm{~mm}$ for mechanical properties. All the samples were replicated five times. The green weight was determined with a digital weighing balance; the longitudinal, radial and tangential axes were measured with a veneer caliper. All samples were oven dried at initial temperature of $70^{\circ} \mathrm{C}$ for 6 hours and thereafter increased to $100^{\circ} \pm C$ to complete 24 hours. This procedure was repeated until a substantial constant weight was obtained and the physical properties calculated. The test for mechanical properties (modulus of rupture and elasticity-MOR and MOE) were performed on an Improvised Universal Testing Machine. The samples were subjected to three point bending test with varying load. At the point of failure, the force exerted that causes the failure was recorded and the MOR and MOE calculated. The results of this study shows a significant $(P=.05)$ variation in wood density (Afzelia africana $>$ Celtis mildbraedii $>$ Meliceae excelsa>Khaya ivorensis $>$ Triplochiton scleroxylon) The MOR $\left(\mathrm{N} / \mathrm{mm}^{2}\right)$ and $M O E$ $\left(\mathrm{N} / \mathrm{mm}^{2}\right)$ of these wood species indicates that Celtis mildbraedii and Afzelia africana has the highest values (149.94/7088 and 136.71/6313), Khaya ivorensis, Meliceae excelsa and Triplochiton scleroxylon has relatively lower values. The test of selected wood species shows that strength of a timber depends on its species and hence different wood species have different strength characteristics. The results obtained in this study has provided quantitative information on the mechanical properties of selected wood species which can be used in determining the application of these wood for either heavy and for building, construction or for other purposes such as the manufacture of furniture.
\end{abstract}

Keywords: Mechanical, Physical, Tropical Rainforest, Wood species, Elasticity

\section{Introduction}

The strength of a timber depends on its species and the effects of certain growth characteristics (Yeomans 2003). Different wood species have different strength characteristics, and also within a species these characteristics may vary. Therefore, in practice, a classification system of strength classes is used. According Fuwape (2000), wood is a fibrous rigid material of plant origin. It is broadly classified as hardwood and softwood. Hardwood is derived from angiosperm or broad-leaved trees such as Iroko (Meliceae excelsa), Lagos Mahogany (Khaya ivorensis), Obeche (Triplochiton scleroxylon), Opepe (Nauclea diderichii) and Danta (Nesogordonia papaverifera). Hardwood timbers are mainly used for structural application because of their high strength and durability. Softwood is obtained from coniferous trees, which have needle-like leaves. Examples of softwood trees are: Scots pine (Pinus sylvestris), Norway spruce (Picea abies), and Douglas fir (Pseudotsuga menziessii)

Physical properties are the quantitative characteristics of wood and its behavior to external influences other than applied forces. Familiarity with physical properties is important because they can significantly influence the performance and strength of wood used in structural applications (Winandy, 1994)

Mechanical properties are the characteristics of a material in response to externally applied forces. They include elastic properties, which characterize resistance to deformation and distortion, and strength properties, which characterize resistance to applied loads. Mechanical property values are given in terms of stress (force per unit area) and strain (deformation resulting from the applied stress). The mechanical property values of wood are obtained from laboratory tests of lumber of straight-grained clear wood samples (without natural defects that would reduce strength, such as knots, checks, splits, etc. (ASTM 1991).

Strength properties mean the ultimate resistance of a material to applied loads. With wood, strength varies significantly depending on species, loading condition, load duration, and a number of assorted material and environmental factors. Because wood is anisotropic, mechanical properties also vary in the three principal 
axes. Property values in the longitudinal axis are generally significantly higher than those in the tangential or radial axes. Flexural (bending) properties are critical. Bending stresses are induced when a material is used as a beam, such as in a floor or rafter system.

The density of a material is the mass per unit volume at some specified condition. For a hydroscopic material such as wood, density depends on two factors: the weight of the wood structure and moisture retained in the wood. Wood density at various moisture contents can vary significantly and must be given relative to a specific condition to have practical meaning. Density is important to indicate strength in wood and may predict certain characteristics such as hardness, ease of machining and nailing resistance. A larger number indicates a stronger wood (Desch and Dinwoodie 1981).

Specific gravity is similar to density and is defined as the ratio of the density of wood to the density of water. Thus, specific gravity is an excellent index of the amount of wood substance contained in a piece of wood; it is a good index of mechanical properties as long as the wood is clear, straight grained, and free from defects. However, specific gravity values also reflect the presence of gums, resins, and extractives, which contribute little to mechanical properties. Some property relationships are nearly linear and others exponential. In fact, mechanical properties within a species tend to be linearly, rather than curvilinear, related to specific gravity; where data are available for individual species, linear analysis is suggested (Green et al., 2003).

The dimensional changes that accompany the shrinking and swelling of wood are major sources of both visual and structural problems involved in the use and application of wood materials. Shrinking and swelling occur as the wood changes moisture content in response to daily as well as seasonal changes in the relative humidity of the atmosphere, i.e., when the air is humid, wood adsorbs moisture and swells; when the air is dry, wood loses moisture and shrinks.

The physical and mechanical properties of wood are important factors used in determining the suitability and application of wood material, these in turn depends on the wood specie. This study was conducted to determine the effect of wood species on some physical properties (Density, Specific gravity, \% volume shrinkage, \% volume swelling and void volume \%) and mechanical properties (Bending strength: modulus of rupture and modulus of elasticity) of five tropical timber species Iroko (Meliceae excelsa), Mahogany (Khaya ivorensis), Obeche (Triplochiton scleroxylon), Apa (Afzelia africana) and Ita (Celtis mildbraedii) in tropical rainforest ecosystem Ondo State, Nigeria.

\section{Material And Methods}

The study was conducted in Ondo State, South West Nigeria. It is an agararian State with land mass of about $14,788,728 \mathrm{~km}^{2}$ and lies within longitudes $4^{0} 30^{\prime}$ and $6^{\circ}$ East of Greenwich meridian and latitudes $5^{0}$ $45^{\prime}$ latitudes $8^{0} 15^{\prime}$ North of the Equator. The climate is the humid sub-tropical indicating that is basically within the tropical rainforest zone which is dominated by broadleaved hardwood trees that form dense layered stands (Adekunle and Olagoke 2010). The mean annual temperature is about $26^{\circ} \mathrm{C}\left(\min .19^{\circ} \mathrm{C}\right.$ and max. $340 \mathrm{C}$ ) and rainfall of $1500 \mathrm{~mm}$ with bimodal rainfall pattern (Oyerinde and Osanyande 2011).

\section{Procurement of materials and Sample Preparation}

The wood species Iroko (Melicea excelsa), Mahogany (Khaya ivorensis), Obeche (Triplochiton scleroxylon), Apa (Afzelia africana) and Ita (Celtis mildbraedii) were obtained from Odode, Adanre local government area, Ondo State, Nigeria. The wood species were machined and trimmed to standard size of $20 \mathrm{~mm}$ x $20 \mathrm{~mm} \times 60 \mathrm{~mm}$ for determination of physical properties and $10 \mathrm{~mm} \times 10 \mathrm{~mm} \times 300 \mathrm{~mm}$ for mechanical properties. The experiment was laid out in Complete Block Design (CBD) and the samples were replicated five times.

\section{Determination of Physical Properties}

The green weight of the samples were weighed with a digital weighing balance, the longitudinal, radial and tangential axes were measured and recorded with a veneer caliper. The samples were dried in an oven at initial temperature of $70^{\circ} \mathrm{C}$ for 6 hours and thereafter increased to $100 \pm 2^{\circ} \mathrm{C}$ to complete 24hours. The samples were removed and transferred to a dessicator and allowed to reach equilibrium temperature in the laboratory before the oven dry weight was obtained. This procedure was repeated until a substantially constant weight was obtained. The swelling and shrinkage was determined by soaking the oven dried sample for 24 hours, and thereafter re-oven dried again to a constant weight. Equations 4 and 5 were used to calculate \% volume shrinkage and volume swelling. The basic density determination based on the green volume and oven-dry weight using a water displacement method was use in the measurement of density.

The physical properties were calculated using the following formulae:

$$
\text { Density }=\frac{\text { Weight of oven dried wood }(\mathrm{kg})}{\text { Volume of } \operatorname{wood}(\mathrm{m} 3)}
$$




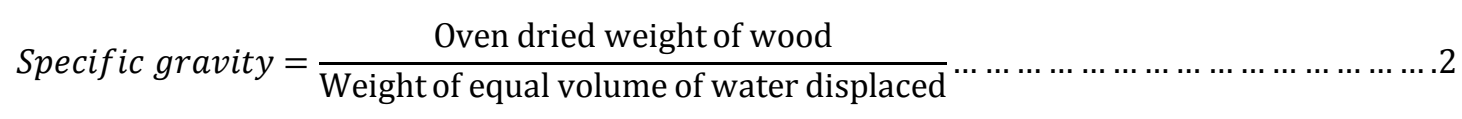

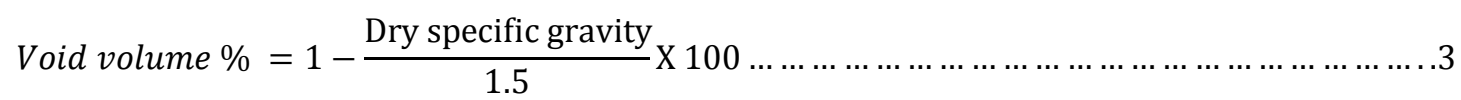

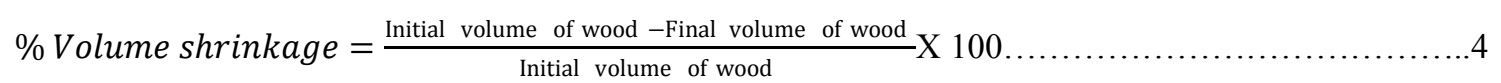

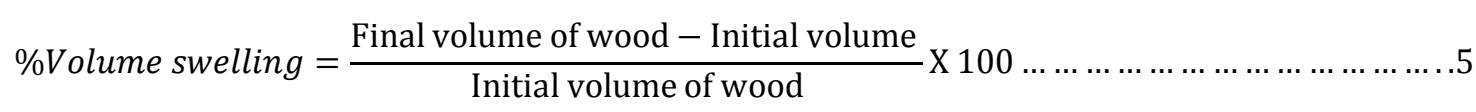

\section{Mechanical Tests}

Mechanical tests conducted on the wood species include: modulus of rupture and elasticity (MOR and MOE). The tests were performed on an improvised wood bending strength frame with digital dial gauge (Improvise Universal Testing Machine) at the wood workshop of the Department of Forestry and Wood Technology, Federal University of Technology, Akure. Samples' dimension of 10mm x 10mm x 300mm, were subjected to three point bending test on the improvised universal testing machine with varying load. At the point of failure the force exerted on the sample that caused the failure was recorded and the MOR and MOE were calculated using the formula:

$$
\begin{aligned}
& M O R=\frac{3 \mathrm{PL}}{2 \mathrm{bd}^{2}} \ldots \ldots \ldots \ldots \ldots \ldots \ldots \ldots \ldots \ldots \\
& \text { Where: } \\
& \text { MOR=Modulus of Rupture } \\
& \mathrm{P}=\text { Load }(\mathrm{N}) \\
& \mathrm{L}=\text { Length of sample }(\mathrm{mm}) \\
& \mathrm{b}=\text { width of the sample }(\mathrm{mm}) \\
& \mathrm{h}=\text { thickness of the sample }(\mathrm{mm}) \\
& M O E=\frac{\mathrm{PL}^{3}}{4 \mathrm{bd}^{3} \Delta} \ldots \ldots \ldots \ldots \ldots \ldots \ldots
\end{aligned}
$$

Where:

$\mathrm{P}=\operatorname{Load}(\mathrm{N})$

$\mathrm{L}=$ Length of sample $(\mathrm{mm})$

$\mathrm{b}=$ width of the sample $(\mathrm{mm})$

$\mathrm{d}=$ thickness of the sample $(\mathrm{mm})$

$\Delta=$ slope of the graph

\section{Results and Discussion}

The mean values of wood density of different wood species are presented in Table 1. The result of analyses of variance shows that there is a significant difference in wood density with respect to wood species. Afzelia africana has the highest wood density, followed by Celtis mildbraedii; Triplochiton scleroxylonhas the lowest density. This shows that Afzelia africana, Celtis mildbraedii and Meliceae excelsa are high density woods and can be used as structural materials such as beams and columns and other support work that requires high strength wood. Khaya ivorensis falls in the category of medium density wood, while Triplochiton scleroxylon is a low density wood. A larger number indicates a stronger wood (Desch and Dinwoodie 1981). The low density wood can mostly be use in the manufactures of furniture and other materials that do not carry heavy loads.

Table 2 indicates the mean \% volume shrinkage values of the wood species. The analyses of variance indicate that there is significant difference among the wood species used in this study. Khaya ivorensis and Celtis mildbraedii has the highest mean \% volume shrinkage and hence possessing high ability to shrinkage when used out door and in high temperature conditions. Melicea excelsa, Afzelia africana and Triplochiton scleroxylon has the medium and low mean values of \% volume shrinkage and hence they possess low ability to shrinkage and can be applied for outdoor uses.

The test of \% volume swelling shows that Celtis mildbraedii has the highest \% mean volume swelling, followed by Khaya ivorensis, this indicates the ability of these wood species to swell when expose to moisture environment. Afzelia africana and Triplochiton scleroxylon has the lowest \% mean volume swelling values and hence their uses and application cannot be much affected by moisture or rainfall (Table 3 ).

In Table 4 the result indicates that Afzelia africana has the highest mean specific gravity value, followed by Celtis mildbraedii. Khaya ivorensis and Triplochiton scleroxylon has the lowest mean values of wood specific gravity. Specific gravity is similar to density and is an excellent index of the amount of wood substance 
contained in a piece of wood; it is a good index of mechanical properties as long as the wood is clear, straight grained, and free from defects. It is important to note that the higher the value of the specific gravity of the wood the greater the strength properties (Green et al., 2003).

The result of the analyses of variance (Table 5) shows that there is significant difference among the various wood species with respect to void volume \%. Triplochiton scleroxylon has the highest void volume $\%$ value, followed by Khaya ivorensis and Meliceae excelsa. Celtis mildbraedii and Afzelia africana has the lowest mean void volume $\%$ values. The void volume percentage is the amount of empty/air spaces comprised by cell cavities and intercellular spaces in a given volume of wood (Liker 2003)

\section{Mechanical Properties of selected wood species Modulus of rupture and elasticity}

The values obtained for the modulus of rupture (MOR) and modulus of elasticity (MOE) from selected wood species is shown in Table 6 . The values show that Celtis mildbraedii has the highest modulus to rupture and elasticity followed by Afzelia africana, Khaya ivorensis and Melicea excelsa. Triplochiton scleroxylon has the lowest modulus of rupture and elasticity. Modulus of rupture reflects the maximum load carrying capacity of a member in bending and is proportional to maximum moment borne by the specimen. These values indicate that Celtis mildbraedii has the highest maximum load carrying capacity and elasticity followed by Afzelia africana, Khaya ivorensis and Meliceae excelsa. Triplochiton scleroxylon has low load carrying capacity and elasticity. The modulus of rupture is an accepted criterion of wood strength (Kretschmann and Bendtsen, 1992). Elasticity implies that deformations produced by low stress are completely recoverable after loads are removed. When loaded to higher stress levels, plastic deformation or failure occurs.

Table 1: Mean wood density of different wood species

\begin{tabular}{llll}
\hline Wood species & Mean density $\left(\mathrm{kg} / \mathrm{m}^{3}\right)$ & \%Moisture content \\
\hline Afzelia africana & $823.81_{\mathrm{a}} \pm 4.09$ & 12.3 \\
Celtis mildbraedii & $732.32_{\mathrm{b}} \pm 4.41$ & 12.4 \\
Meliceae excels & $650.41_{\mathrm{c}} \pm 1.29$ & 12.6 \\
Khaya ivorensis & $525.83_{\mathrm{d}} \pm 3.06$ & 13.3 \\
Triplochiton scleroxylon & $372.46_{\mathrm{e}}$ & \pm 5.88 & 12.2 \\
\hline Significance & $*$ & \\
\hline
\end{tabular}

Means with the same letter are not significantly different (Duncan's Multiple Test at $P=.05$ )

*: Significant

Table 2: Mean \% volume shrinkage

\begin{tabular}{ll}
\hline Wood species & Mean \% vol. shrinkage \\
\hline Khaya ivorensis & $12.94_{\mathrm{a}} \pm 0.08$ \\
Celtis mildbraedii & $12.29_{\mathrm{b}} \pm 0.00$ \\
Meliceae excelsa & $9.19_{\mathrm{c}} \pm 0.00$ \\
Afzelia Africana & $7.57_{\mathrm{d}} \pm 0.37$ \\
Triplochiton scleroxylon & $6.90_{\mathrm{e}} \pm 0.52$ \\
\hline Significance & $*$ \\
\hline
\end{tabular}

Means with the same letter are not significantly different (Duncan's Multiple Test at $P=.05$ ) *: Significant

Table 3: Mean \% volume swelling of different wood species

\begin{tabular}{ll}
\hline Wood species & Mean \% vol. swelling \\
\hline Celtis mildbraedii & $11.36_{\mathrm{a}} \pm 0.08$ \\
Khaya ivorensis & $10.46_{\mathrm{b}} \pm 0.00$ \\
Meliceae excelsa & $10.12_{\mathrm{c}} \pm 0.00$ \\
Afzelia Africana & $7.50_{\mathrm{d}} \pm 0.37$ \\
Triplochiton scleroxylon & $6.44_{\mathrm{e}} \pm 0.52$ \\
Significance & $*$ \\
\hline
\end{tabular}

Means with the same letter are not significantly different (Duncan's Multiple Test at $P=.05$ )

*: Significant

Table 4: Mean specific gravity of different wood species

\begin{tabular}{ll}
\hline Wood species & Mean Specific gravity \\
\hline Afzelia Africana & $0.84_{\mathrm{a}} \pm 0.01$ \\
Celtis mildbraedii & $0.79_{\mathrm{b}} \pm 0.01$ \\
Meliceae excelsa & $0.64_{\mathrm{c}} \pm 0.01$ \\
Khaya ivorensis & $0.58_{\mathrm{d}} \pm 0.01$ \\
Triplochiton scleroxylon & $0.38_{\mathrm{e}} \pm 0.01$ \\
Significance & $*$ \\
\hline
\end{tabular}

Means with the same letter are not significantly different (Duncan's Multiple Test at $P=.05$ )

*: Significant 
Table 5: Mean void volume of different wood species

\begin{tabular}{ll}
\hline Wood species & Mean void vol. \% \\
\hline Triplochiton scleroxylon & $74.49_{\mathrm{a}} \pm 0.54$ \\
Khaya ivorensis & $61.37_{\mathrm{b}} \pm 0.50$ \\
Meliceae excelsa & $57.63_{\mathrm{c}} \pm 0.64$ \\
Celtis mildbraedii & $47.23_{\mathrm{d}} \pm 0.86$ \\
Afzelia africana & $44.14_{\mathrm{e}} \pm 0.92$ \\
Significance & $*$ \\
\hline
\end{tabular}

Means with the same letter are not significantly different (Duncan's Multiple Test at $P=.05$ )

*: Significant

Table 6: MOR and MOE from selected wood species

\begin{tabular}{lll}
\hline Wood species & MOR $\left(\mathbf{N} / \mathbf{m m}^{2}\right)$ & $\left(\mathbf{M O E} \mathbf{N} / \mathbf{m m}^{2}\right)$ \\
\hline Celtis mildbraedii & 149.94 & 7088.69 \\
Afzelia africana & 136.71 & 6313.58 \\
Khaya ivorensis & 94.82 & 8192.54 \\
Meliceae excelsa & 90.41 & 5765.63 \\
Triplochiton scleroxylon & 30.87 & 3937.5 \\
\hline
\end{tabular}

\section{Conclusion}

The test of selected wood species shows that strength of a timber depends on its species and hence different wood species have different strength characteristics. The results obtained in this study has provided quantitative information on the mechanical properties of selected wood species which can be used in determining the application of these wood for either heavy and for building, construction or for other purposes such as the manufacture of furniture.

\section{Acknowledgements}

The authors would like to extend their sincere gratitude to all the staff of Wood Workshop of the Department of Forestry and Wood Technology, Federal University of Technology, Akure, Nigeria.

\section{References}

[1]. Adekunle, V.A.J. and A.O. Olagoke 2010. Timber Harvest in Tropical Ecosystem, Ondo State, Nigeria: Implication on Carbon Release. In Climate change and forest resources management: the way forward (Onyekwelu, J.C., Adekunle, V.A. Oke, D.O.Editors) Procedings of the Second National Conference of the Forests and Forest Products Society, field at the Federal University of Technology, Akure, Nigeria. 26-29 April 2010 pp. 183-192

[2]. American Society for Testing and Materials 1991. Annual Book of Standards, Vol. D.09 Wood.Philadelphia, PA. (http://www.fpl.fs.fed.us/documnts/pdf1994/winan94a.pdf)

[3]. Desch, H.E. and J.M. Dinwoodie 1981. Timber, Its Structure, Properties and Utilization. The Macmillan press Ltd., london

[4]. Fuwape, J. A. 2000. 25th Inaugural Lecture of the Federal University of Technology, Akure.

[5]. The title of this lecture: "Wood Utilization: From cradle to the grave" highlights the importance of wood products to every sphere of human life in facilitating environmentally, friendly technological innovations for sustainable development.http://www.nuc.edu.ng/nucsite/File/ILS\%20\%202000\%20EDITED/ILS-22.pdf

[6]. Green, D.W.; Evans, J.W.; Craig, B.A. 2003. Durability of structural lumber products at high temperatures I: $66^{\circ} \mathrm{C}$ at $75 \%$ RH and $82^{\circ} \mathrm{C}$ at $30 \%$ RH. Wood and Fiber Science. 35(4): 499-523.

[7]. Kretschmann, D.E.; Bendtsen, B.A. 1992. Ultimate tensile stress and modulus of elasticity of fast-grown plantation loblolly pine lumber. Wood and Fiber Science. 24(2): 189-203.

[8]. Liker, U. 2003.Comparative Study of Wood Density by Specific Amount of Void Volume (Porosity).Turk J Agric 27 1-6

[9]. Oyerinde, O.V. and Osanyande, O.V. 2011 Farmers' Adaptation Strategies and Perception to Climate Change: A Case Study of Communities AroundIdanre Forest Reserve, Ondo State, Nigeria. In Climate change and forest resources management: the way forward (Onyekwelu, J.C., Adekunle, V.A. Oke, D.O.-Editors) Procedings of the Second National Conference of the Forests and Forest Products Society, field at the Federal University of Technology, Akure, Nigeria. 26-29 April 2010 pp. 233-237.

[10]. Winandy, J.E. 1994. Effects of long-term elevated temperature on CCA-treated Southern Pine lumber. Forest Products Journal. 44(6): 49-55.

[11]. Yeomans, D. 2003. Strength Grading Historic Timbers. Cathedral Communications Limited 2010 (http://www.buildingconservation.com/articles/gradingtimbers/gradingtimbers.ht) 